\title{
CODE - MIXING IN ENGLISH CLASSES OF SMPN 14 KOTA BENGKULU: VIEWS FROM THE TEACHERS
}

\author{
Tri Ramadhaniarti \\ Safnil \\ Arono \\ Postgraduate Program of English Education \\ Faculty of Teacher Training and Education Bengkulu University. \\ triramadhaniarti@gmail.com
}

\begin{abstract}
English teachers in all levels of education in Indonesia try hard to make their students able to speak and write English. Teachers sometimes use code-mixing in their classroom instructions. This study is conducted to investigate Code - Mixing in English Classes of SMPN 14 Kota Bengkulu: Views From the Teachers. The participants were the English teachers who teach English at SMPN 14 Kota Bengkulu. The data were collected from audio-recording and interviewing to the teachers. The results indicated that teachers used inter-sentential code-mixing more frequently than intra-sentential codemixing. It also found that all of the teachers used code-mixing in pre-activity, while activity and post-activity of teaching and learning process in their English classes. They also used code-mixing for giving instruction, translation and asking for clarification. The English-Indonesian pattern is the most frequently used by the teachers in teaching English. The teachers used code-mixing in teaching English in the English classes to make the students able to understand the purpose of teaching and learning process easily.
\end{abstract}

Keywords: code-mixing, inter-sentential code-mixing, intra-sentential code-mixing

Abstrak: Guru-guru bahasa Inggris di semua tingkat pendidikan di Indonesia mencoba membuat siswa-siswanya mampu berbicara dan menulis dalam bahasa Inggris. Guru kadang-kadang menggunakan alih kode (code-mixing) dalam komunikasi di kelas. Penelitian ini meneliti tentang alih kode di kelas bahasa inggris di SMPN 14 Kota Bengkulu : Pandangan dari Guru. Subjek penelitian ini adalah guru-guru yang mengajar Bahasa Inggris di SMPN 14 Kota Bengkulu. Data di kumpulkan dari rekaman dan wawancara kepada guru-guru. Hasilnya menunjukkan bahwa guru-guru menggunakan alih kode antar kalimat lebih banyak daripada alih kode dalam kalimat. Penelitian ini juga memukan bahwa semua guru menggunakan alih kode di aktivitas awal, selama aktivitas dan di akhir aktivitas proses belajar dan mengajar di kelas bahasa Inggris. Mereka menggunakan alih kode untuk memberikan perintah, menerjemahkan kata dan memberikan penjelasan. Pola bahasa Inggris-bahasa Indonesia paling banyak digunakan oleh guru-guru dalam mengajar bahasa Inggris. Guru menggunakan alih bahasa dalam mengajar bahasa Inggris di kelas-kelas Bahasa Inggris untuk membuat siswa mengerti tujuan dari proses belajar mengajar dengan mudah.

Kata Kunci : Alih kode, Alih kode antar kalimat, alih kode dalam kalimat.

\section{INTRODUCTION}

English teachers in all levels of education in Indonesia try hard to make their students can speak and write English. To make their teaching and learning success, they sometimes mix 
English with Bahasa Indonesia in their classroom instructions. All language classrooms input must be in the target language. An effective model of language used can ensure that the intended learning was successful (Krashen cited in Ahmad, 2009). Therefore, classroom instructions from the teacher are most valuable input for learners in English classes.

Code - mixing (CM) is shifting from one language to another in a conversation. It refers to the combination of several languages or dialects in the same conversation or sentence by bilingual people (Gardner-Chloros, 2009 cited in Horasan, 2014). We can find it in everyday practice among people in the world for various reasons and usually a unconscious activity. This language mixing not be the whole sentence, but also can occur in brief phrases or words, in this case the teachers mix English (L2) with Bahasa Indonesia (L1). They use their first language (L1) and their second language (L2) in different domains. They do this is not only used in everyday communication but also in the classroom interaction between teacher and students, and students and students. We call this as classroom code-mixing.

English as an international language has been taught in many countries in this world as a foreign or second language. As a foreign language, English is also taught in Indonesia because English is one of the lessons in every level of education from elementary school until University level. In this study especially in Junior High School level. It is stated in Peraturan Menteri Pendidikan dan Kebudayaan No. 68 Tahun 2013, it is about "Kerangka Dasar dan Struktur
Kurikulum Sekolah Menengah Pertama / Madrasah Tsanawiyah". It is clear that English is a main lesson in Curriculum for Junior High School level in Indonesia.

Based on KTSP (Kurikilum Tingkat Satuan Pendidikan) in Junior High School level, there are four skills in English that should be taught to the students, they are listening, speaking, reading and writing. In those skills, teachers sometimes use code-mixing in teaching English. They do this because of many reasons. One of the reasons is to achieve teaching English goals. It is found by David Chen (2009), conducted a study about Teacher Code-Switching in Secondary English and Science in Malaysia. English lessons necessitates use of code-mixing / code-switching to convey the message to the students. Code mixing is also a necessary tool for teachers to achieve teaching goals and to make teachers' messages more comprehensible to students.

Based on researcher's observation at SMPN 14 Kota Bengkulu, teachers mix English with Bahasa Indonesia is an usual thing to do in teaching and learning process in English classes. Rezvani.E and Rasekh.AE (2011) also found that code switching is a frequently applied strategy and a valuable resource for bilingual teachers in foreign language classrooms, and its judicious and skillful use can boost the quality of teaching.

The phenomenon of teachers using their first language when teaching a second language is a form of codemixing and it is common to occur in situations where the teacher and the students share the same language or mother tongue. The use of Indonesian 
was common among both the teacher and the students. In my experience, I found that was hard to maintain and that it sometimes actually seemed to benefit the students more to use Indonesian instead of English. This phenomena makes researcher interested to do analyzing why code - mixing is necessary for teachers in teaching English.

According to Muysken (cited in Didar H., 2015), "Code-mixing is a process in which lexical items and grammatical features of two or more languages exist in the same sentence. In another book, Muysken ( cited in Didar H., 2015) used the term code-mixing to refer "to all cases where lexical items and grammatical features from two languages appear in one sentence. Based on Jendra (cited in Sumarsih. 2014) "Code-mixing is a symptom of language usage in which 'a mixing or combination of different variations within the same clause'. The mix of code mixing describe in the sentence: "This morning I sudah bawa my baby tu near babysitter lah". Based on this example occurs code mixing due to mixing speakers of both language (code) in a mixed sentence. On code means there is a dominant language used, e.g. in the predominantly English speaking. Speech as the dominant Indonesian officials, but interspersed with the occasional foreign language to make it look cool or acceptable. So that it can be concluded that code-mixing is a mixture between two or more languages in which there is a dominant language and inserted with different language to make it sound cool and give appropriate context to the listener.

Code-mixing is actually the mixing of different varieties of language. It refers to mixing of two different codes within a sentence. Wardhaugh (1992) defines code-mixing as the deliberate use of two languages without an associated topic change. It is basically found in multilingual places. It is closely related to code-switching. Code-mixing does not necessarily result in a change of topic or section. It occurs when conversant use both languages together to the extent that they change from one language to the other in the course of a single utterance. This kind of alteration is called codemixing.

The purpose of code-mixing seems to symbolize a somewhat ambiguous situation for which neither language on its own would be quite right. To get the right effect the speakers balance the two languages, then a few words of the other, and then back to the first for a few more words and so on. The changes generally take place more or less randomly as far as subject-matter is concerned, but they seem to be limited by the sentencestructure. Based on Didar H. ( 2015 ) Code-mixing involves mixing of:A). Two languages, B). Two or more languages, C). Two or more diglossic varieties'

\section{METHODOLOGY}

This study applied a qualitative research design based on the classifications of the research design from Djajasudarma (2006), this study can be characterized as a qualitative study and it categorized as a case study because the research was carried out in a limited or small scale single case and not to be generalized. In this study, the research only dealt with analyzing particular document from the interview to all of 
the English Teachers and recording teaching and learning process of the three English teachers who teach in grade IX at SMPN 14 Kota Bengkulu. Then, the results was not to be generalized as general conditions of the whole teachers in Kota Bengkulu. In gaining the data, researcher conducted naturally without making the hypothesis for the study.

Researcher chose SMPN 14 Kota Bengkulu as the place to carry out this study, because researcher is one of the English teachers in this school and researcher felt convenience to carry out this study here. Convenience factor should be taken into consideration to support the researcher to carry out the research (Aswasilah : 2009 cited in Refdi: 2012). The researcher is also familiar with the participants as well as professional relationship with them, that also helped researcher to carry out this research.

The participants of this study were six English teachers in SMPN 14 and three English teachers who teach in ninth grade of junior high school at SMPN 14 Kota Bengkulu. They all are professional teachers, it can be proof by the certificates they have as the professional teachers from the government. The teachers chosen by researcher because researcher intended to discover the views from the teachers based on valid information from the participants. Therefore, the participants belonged to the teachers who teach English in this school.

An audio-recording and interviewing were used as the instruments in order to get the data from the teachers. The audiorecording was used to discover the types of code-mixing used by the teachers most frequently in conversational discourse and the pattern of code-mixing used by the teachers. The interviewing was used in order to get the data about the reason of the teachers using code-mixing in English classes of Junior High School.

The audio-recording would be done while teaching and learning process in the classroom. Afterwards, the records were transcribed in order to compute the occurrences of types of code-mixing and the patterns of code-mixing. The types of analysis were intra-sentential codemixing ( phrase, words, clause or sentence) and inter-sentential codemixing (outside the phrase, clause or sentence).

First step is recording the data from the respondents. The recording would be taken while teaching and learning processes by using three recorders. Researcher just put the recorders on the tables. One recorder put on the first row of the table, second recorder put on the middle of student's table and the third recorder put on the last row of the student's table. Researcher would not stay in the classroom while recording because the teachers said that they would not feel comfortable if the researcher stayed in their classroom. After that, the recording would be transcribed, Then, it would be analyzed by three inter raters / coders reliability into the types of code mixing, they are (1) intra-sentential code-mixing, and (2) inter-sentential code-mixing. Then, it would be percentage by using a formula.

The formula would be used as proposed by Sugana, (1986), cited in Dewi, (2013):

$\mathrm{F}$
$\mathrm{P}=\mathrm{-}$
$\mathrm{n}$




$$
\begin{aligned}
& \mathrm{F}=\text { Frequency } \\
& \mathrm{n}=\text { Total of code-mixing }
\end{aligned}
$$

The interviewing was used as an instrument too in order to gain the information of the teachers' reasons in using code-mixing in English classes at SMPN 14 Kota Bengkulu. The transcript of the interview is defined as "any written documents that present respondents with series of questions or statements to which they are to react either by writing out their answers or selecting among existing answers ( Brown: 2001 as cited in Refdi: 2012).

The interview is a way of collecting data to take direct information from the resource (Riduwan, 2007). The interview would be done to get the information from the respondents about why the teachers use code-mixing at Junior High School English Class, in this case the code-mixing used by the teachers as the respondents. The interview consist of series of questions, the respondents have freedom to explain and answer the questions from the interview. The interview were conducted in English and the teachers had to answer in English too because they all are English teachers. This interview was a structured question which the questions are totally made by the researcher ( Nunan, 1992). The questions that the teachers were asked dealt with their code-mixing habits and opinions of code-mixing they use in the English classes.

In this study, data analyses were conducted over the course of study. The data analyses and interpretation were based on data from the interview to the participants and audio-recording from teaching and learning process in the classroom.

\section{FINDING AND DISCUSSION}

There are three raters who analyzed the audio-recording and six teachers as the respondents for the interview in this study. The raters are English teachers in Junior High School and also the students of English Education Postgraduate Study Program. They are chosen as the raters because they understand well about the code-mixing utterances so that it really helps researcher to identify and analyze the types of code-mixing. Two weeks needed by researcher to make the transcription from the audio recording and then two weeks needed by raters to analyzed them. Mean while, the six teachers as the respondents for the interview in this study are the English teachers of SMPN 14 Kota Bengkulu. They all are professional teachers and have been teaching English for more than 16 years so that they have good experiences in teaching English and it can be said that they are experienced teachers.

To know about the types of codemixing used by teachers in English classes, the researcher used audio recording while teaching and learning process in the classroom. Here is the total number of code-mixing utterances and their types distribution.

The result is shown in table 1 . 


\begin{tabular}{|c|c|c|c|c|c|c|}
\hline No & Types & Teacher & $\begin{array}{l}\text { Teachers' } \\
\text { Utterances }\end{array}$ & $\begin{array}{l}\text { Total of } \\
\text { Teacher's } \\
\text { Utterances }\end{array}$ & Average & $\begin{array}{l}\text { Percentage } \\
(\%)\end{array}$ \\
\hline \multirow[t]{3}{*}{1.} & \multirow{3}{*}{$\begin{array}{l}\text { Intra- } \\
\text { sentential } \\
\text { code- } \\
\text { mixing }\end{array}$} & $1^{\mathrm{st}}$ & 16 & \multirow{3}{*}{53} & \multirow{3}{*}{17,66} & \multirow{3}{*}{44,54} \\
\hline & & $2^{\text {nd }}$ & 15 & & & \\
\hline & & $3^{\text {rd }}$ & 22 & & & \\
\hline \multirow[t]{3}{*}{2.} & \multirow{3}{*}{$\begin{array}{l}\text { Inter- } \\
\text { sentential } \\
\text { code- } \\
\text { mixing }\end{array}$} & $1^{\mathrm{st}}$ & 26 & \multirow{3}{*}{66} & \multirow{3}{*}{22,33} & \multirow{3}{*}{55,46} \\
\hline & & $2^{\text {nd }}$ & 23 & & & \\
\hline & & $3^{\text {rd }}$ & 17 & & & \\
\hline & TOTAL & & 119 & 119 & & 100 \\
\hline
\end{tabular}

Table 1. Types of code-mixing used by the teachers

Table 1. indicates that the teachers used two types code-mixing, they were Intra-sentential code-mixing (within phrase, words, clause or sentence) and Inter-sentential code-mixing (outside the phrase, clause or sentence). Intersentential code-mixing which is emphasizes the most in teaching English used by the teachers of junior high school, it is found 66 times of utterances, while the average of inter-sentential code-mixing used by each the teacher is 22,33 times and it is about $55,46 \%$ from the total utterances. It is followed by intra-sentential code-mixing. The teachers used inter-sentential codemixing in three activities in teaching, preactivity, while activity and post activity. The higher frequency occurrence for inter-sentential code-mixing can be attributed to teachers' intention of giving clearer instruction and eliciting more responses (Qian et al., 2009) or sustaining students' interest and encouraging their participation (Richards, 1998).

The Patterns of Code-mixing

The table below showed the transcription analysis of code-mixing pattern used by the teachers. We can see the number of code-mixing patterns were addressed to the students by the teachers while teaching and learning process in the English classrooms

Table 2. The frequency of the Patterns of Code-Mixing

\begin{tabular}{|c|l|c|c|}
\hline $\begin{array}{c}\mathrm{N} \\
\mathrm{o}\end{array}$ & Patterns & $\begin{array}{c}\text { Frequen } \\
\text { cy }\end{array}$ & $\begin{array}{c}\text { Percenta } \\
\text { ge }(\%)\end{array}$ \\
\hline 1 & $\begin{array}{l}\text { English- } \\
\text { Indonesi } \\
\text { an }\end{array}$ & 62 & 52,10 \\
\hline 2 & $\begin{array}{l}\text { Indonesi } \\
\text { an- }\end{array}$ & 7 & 5,88 \\
\hline
\end{tabular}




\begin{tabular}{|c|l|c|c|}
\hline 3 & English & & \\
\hline 3 & $\begin{array}{l}\text { English- } \\
\text { Indonesi } \\
\text { an- } \\
\text { English }\end{array}$ & 32 & 26,89 \\
\hline & $\begin{array}{l}\text { Indonesi } \\
\text { an- } \\
\text { English- } \\
\text { Indonesi } \\
\text { an }\end{array}$ & 18 & 15,13 \\
\hline & Total & 119 & 100 \\
\hline
\end{tabular}

In this research, it is found that there are four patterns used by the teachers. The teachers mostly used EnglishIndonesian pattern, 62 times from 119 times of utterances. They use EnglishIndonesian pattern quite a lot, it about 52,10\%. They used English first then they mixed to Indonesian. The sample of this kind of English-Indonesian pattern.

The reasons of the teacher using codemixing in English classes of Junior High School

It is found that teachers' reason used code mixing in teaching is the purpose of teaching and learning process more understand easily to students, their students have limited vocabulary, poor English, and students can not understand their teachers' if the teachers use full sentences in English.

The aim of this study was to discover the type of code-mixing used by teachers most frequently in conversational discourse in English classes of Junior High School, the patterns of code-mixing used at Junior High School English Classes and the reason of the teachers use code-mixing in English classes of Junior High School.

The first question for this research is what the type of code-mixing used by teachers most frequently in conversational discourse in English classes of Junior High School. The result of this research shows that Intersentential code-mixing is used most frequently by the teachers of grade IX of SMPN 14 Kota Bengkulu. This result is similar to the previous study (Horasan, 2014). Rezvani (2011), in his research also found that inter-sentential switching occurred more frequently than intrasentential code-switching because the teachers seemed to be concerned that his students may not understand the directions correctly in the target language, so he resorted to students first language to help their comprehension.

Inter-sentential mixing was practiced by the most balanced bilinguals only (Poplack,1980). It can be said that the teachers used inter-sentential codemixing because they are able to speak two languages fluently in the same time. The teachers used inter-sentential codemixing in three activities of teaching, they are pre-activity, while-activity and post activity. It is proved by Jingxia (2010) in her research about teacher's code-switching to the L1 in EFL classroom, she found that inter-sentential code-switching is the dominant one used by the teachers in EFL classroom.

The second question of this research is on the patterns of code-mixing used at Junior High School English Classes. Four patterns are found that teachers used during the teaching and learning process in the English classes. The patterns are English-Indonesian, Indonesian-English, English-Indonesian-English and Indonesian-English-Indonesian.

Among the four patterns, EnglishIndonesian is the most frequently used 
by the three teachers. The teacher is the only one of English speaker model in the classroom, they have to give input in English to the students. The input must be in target language so that she/he has to speak English as much as possible to make the learning process successful (Krashen cited in Ahmad, 2009). It is supported by Josefsson (2010) in her journal, she said that the more the students hear English the better it is for their language development.

The third question of this research is about the teachers' reasons in using codemixing in English classes of Junior High School. The language function of codemixing that the teachers used because of giving instruction, asking for clarification and translation the new English words. They used code-mixing for two main reasons, first, the information would be easy understood by the students and second it is because students' lack of vocabulary. Grosjean (1982) states that people switch when they cannot find the suitable term or when the language being used does not have the appropriate translation. Here, the teacher translate the English word directly to the students because it seem that the teacher had no other way to explain the word instead of translate it into Indonesian.

Teacher said code-mixing help her students to understand and comprehend the concepts and terms in English, teachers' code-mixing is helpful in solving this problem. This study found that code-mixing helps students to enjoy their learning due to their ability to comprehend the teacher's input. The comprehensible input allowed them to feel less stressful and to become more comfortable to learn. Once they are comfortable with the environment, without any unnecessary anxiety (lai, 1996; Chi, 2000; Burden, 2001). The teacher would give the instruction in English, then if the students did not understand or no respond from the students, the teacher will mix the language with Indonesian.

Using English as much as possible in the classroom was taken for granted by the teachers, beside to teach students to learn English, teacher needs to communicate in English, but the teachers felt that the students would be understand better if they talk in Indonesian instead of English. The reason of using code mixing in teaching English is the same as the finding of research from China by Shujing (2013). He found the possible reason for using code-mixing by the teachers. It was, the teacher fell that the content is extremely important and therefore uses code-switching to make sure that the information is conveyed.

\section{CONCLUSION AND SUGGESTIONS}

Based on the above discussion, several conclusions can be drawn from this study based on the research results and discussion. First, the type of codemixing which is the most frequently used in teaching English by the teachers of junior high school is Inter-sentential code-mixing. Inter-sentential codemixing could be found in three activities of teaching and learning process in the classroom, they are pre-activities, while activities and post-activities,

The second, it is found four patterns that teachers used during the teaching and learning process in the English classes. The patterns are EnglishIndonesian, Indonesian-English, English- 
Indonesian-English and IndonesianEnglish-Indonesian. Among the four patterns, English-Indonesian is the most frequently used by the three teachers. The English should be used as much as possible in the classroom was taken for granted by all the teachers. It is interesting that students appreciate teachers' using English most of the time but also complain that they do not understand it when the teachers speak only English in the English class.

The third, the reason of the teachers to use code-mixing in English classes is because the teachers want their teaching and learning would be understand easily by the students and the teacher found that their students have limited vocabulary so that they think it is necessary to use codemixing in their teaching and learning process. They usually used code-mixing in while activity in teaching. The teacher wanted the lesson would be understandable by the students. Codemixing really help the students to understand and comprehend the meaning of the words, sentences and phrases. Code-mixing is one of the teachers strategies to help them build interaction to the students in the classroom. Teachers think it is necessary to used code-mixing in teaching in English classes because code-mixing also could contribute a better teacher-students classroom interaction and communication. Codemixing helped them in giving instruction, translate the new English words and clarify the lesson to the students.

Based on the result of this study which has been explained in the previous chapter, there are some suggestions which related to this study. It is stated as follows:

\section{For English Teachers}

First, it is found that the teachers used inter-sentential code-mixing in teaching English. Here, I suggest it is better if the teacher not translating the new words directly. Try to explain the new words by using body language and media such as guessing picture or bring the real thing of that thing. By using this way students will remember the word longer.

Second, it is found that the pattern English-Indonesian used by teachers mostly. It is good that the teachers have tried to speak English as much as possible in their English classes as the model for their students but even teachers have tried to speak English as much as possible, I suggest it is better to reduce using Indonesian in English classes because the students is in the ninth grade of Junior High School level. It means they have been studying English for three years, it does not mean that the students know nothing about English so that it is no need for teachers to translate every single words or sentences.

Third, generally the teachers' reason using code-mixing in teaching English in their English classes is to make their students understand the English materials easily because their students have limited vocabulary. But here, again, the teacher have to consider the level of students when they use code-mixing in teaching. The occurrences of code-mixing are acceptable in lower levels (Arifin, 2009). Since the level of the students is low, teachers may feel needed to employ lot of code-mixing to facilitate understanding and attract students' attention. Try to teach them understand English from the context of the language. 
2. For other Researchers

The area of code-mixing among teachers could very well be studied further. Further study can be conducted in a large scale with a larger sample. Future studies may also conduct at investigating the effect of code-mixing on students' learning in second language context, the relationship between using English-Indonesian and IndonesianEnglish to students' achievement and the effect of using English-English dictionary in teaching English. The researcher hopes that this result of this study can give more information for the readers that code-mixing is one of strategies in teaching English.

\section{REFERENCES}

Ahmad, B.H and Jusoff. K. (2009). Teachers' Code-Switching in Classroom Instructions for Low English Proficient Learners. English Language Teaching Journal. Vol. 2, No. 2, pp. 4945, June 2009. www.ccsnet.org/journal.html. December -5th-2011.

Aprianti, F (2014) Classroom Interaction : An analysis of teachers language choice of L1 and TL in EFL Classroom. Universitas Pendidikan Indonesia

Arifin, K., \& Rafik-Galea, S. (2009). Code-switching as a communication device in conversation. Language \& Society Newletter, 5. Retrieved from November 30. 2012.

Brown, D (2001) Teaching by Principle; An interactive approach to Language Pedagogy $\left(2^{\text {nd }}\right.$ ed. Longman).
Burden, P. (2001). When do native English speakers and Japanese college students disagree about the use of Japanese in English converstion classroom? The language teacher (April 2001).

Chi, W.C, (2000). The importance of bilingual teachers to Chineseoriented AMEP Learners. http://www.und.ac.za/und/ling/a rchieve/chic-04.html.

Cook, Vivian (2001) Using the first language in the classroom. Canadian Modern Language Review.

David, C and Su-Hie Ting (2009) A Preliminary Study of Teacher Code-Switching in Secondary English and Science in Malaysia. Vol. 13 No. 1. Universiti Malaysia Sarawak

Dewi, A.P (2013) Code switching in Indonesia Idol 2012 Program : A case Study of the Judges' Comments and Viewers' Attitude. Universitas Pendidikan Indonesia.

Depdikbud (2013) Peraturan Menteri Pendidikan dan Kebudayaan No. 68 Tahun 2013. Tentang Kerangka Dasar dan Struktur kurrikulum Sekolah Menengah Pertama / Madrasah Sanawiyah.

Didar. H, (2015) A case study in CodeMixing among Jahangirnagar University Students, Vol.6(7), pp. $123-139$. DOI: 10.5897/IJEL2015.0782 ISSN: 2141-2626

Djajasudarma, F. (2006). Metode Linguistik - Ancangan Metode Penelitian dan kajian. Bandung: PT Refika Aditama 
Dulm O.v and Rose. S., (2006) Function of Code-switching in Multilingual Classrooms. Journal for Language Learning. 22 (2) : 1-13. University of Stellenbosch

Grosjean,F. (1982). Life with two languages: An introduction to bilingualism. Cambridge, MA: Harvard University Press.

Halmari, Helena (2004) Code-switching pattern and developing discourse in L2. In Boxer, Diana \& Cohen, Andrew D. Studying speaking to inform second language learning. Cleverdon: Multilingual Matters.

Horasan, S. (2014) Code-switching in EFL classroom and the perceptions of the students and the teachers. Journal of Language and Linguistics Studies, 10(1) , 31-45; 2014

Jessica. J.C (2010) An Analysis of Trainee Teachers' use of Codeswitching in the Bilingual Secondary Classroom: a case from Wales. Vol. 3 (1). Bangor University

Jingxia, L. (2010) Teachers' CodeSwitching to the L1 in EFL classroom. Open Applied Linguistics Journal. 3. $10-23$. Three Gorges University

Josefsson, R. (2010) Code-switching in the English Classroom Six Teachers' Teory and Practice. Estetisk-filosofiska fakulteten. Karlstads Universitet 65188 Karlsad.

Lai, Mee-Sing. (1996). Using the 11 sensibly in English language classroom. http://sunzi 1.lib.hku.hk/hkjo/view/48/4800 045. Pdf.

Poplack, S. (1980) Sometime I'll start a sentences in Spanish Y termino en espanol : toward a typology of code-switching. Linguistic 18, 7/8. 581-618

Qian, X., Tian, G. Wang, Q. (2009). Codeswitching in the primary ELF classroom in China-two case studies. System 37, 719730.

Refdi, A (2012) A systematic Analysis of High School Teachers' Argumentative Writing: A Case Study in Bandar Lampung. S2 Thesis, Universitas Pendidikan Indonesia.

Rezvani. E. and Rasekh. AE., ( 2011) Code-switching in Irania Elementary EFL Classrooms: An Exploratory Investigation. Vo. 4 No. 1. University of Isfahan, Iran.

Richards, J.C. (1998). What's the use of lesson plans? In J.C. Richards (Ed), Beyond Training (pp. 103121). Cambridge: Cambridge University Press.

Shujing, Wu (2013) Teachers' codswitching in the ESP classroom in China. Studies in Sociology of Science Vol. 4 No. 4. University Binzhou, China.

Sumarsih. (2014). Code-switching and code-mixing in Indonesia: Study in sociolinguistics. English Language and Literature Studies (Vol. 4, No. 1, February 2014)

Tuma, F (2014) Dialogism and classroom interaction in English language 
teaching: A review of Czech research. Article 24(6), 878902. Masaryk University.

Wallen, Norman E., and Fraenkel, Jack R. (1991) Educational Research: A Quide to the
Process. New York, NY: MC Graw-Hill inc.

Wardhaugh R (First published: (1986), second edition: (1992) An Introduction to Sociolinguistics. Oxford: Blackwell Publishers. 